\title{
The Effect of IPSAS on Reforming Governmental Financial Reporting: an International Comparison
}

\author{
ID IRAS-2013-046.R1
}

Paper submitted for IRAS April 2013, revised September 2013, revised November 2013, accepted December 2013

\begin{abstract}
Over the past 25 years significant New Public Management (NPM) reforms, particularly towards accrual accounting, have characterized the public sector in many countries. The diversity in public financial information systems created a need for harmonization, resulting in the elaboration of International Public Sector Accounting Standards (IPSAS). Despite their relevance, little is known on the adoption process of IPSAS. This study aims to examine to what extent IPSAS(-like) accrual accounting is adopted in central / local governments worldwide as well as to investigate which factors affect the differing level of their adoption. Methodologically, a specific questionnaire constructed to obtain relevant information from local experts was sent worldwide to a sample of countries. The study reveals an important move to accrual accounting, particularly to IPSAS-accrual accounting whereby there still remains a level of reluctance mainly in central governments, especially in countries where businesslike accrual accounting has been developed.
\end{abstract}

\section{Points for practitioners}

IPSAS have become the international reference for the development of public sector accounting systems worldwide. For this reason, IPSAS deserves the attention of accounting policy-makers, practitioners and scholars. The current study offers a comparative study of the level of adopting IPSASs worldwide as well as an explanation of the reasons behind the differing levels of adoption. The present study reveals that the transition towards IPSAS necessitates a long period of implementation whereby existing local business accounting regulations hinder jurisdictions to implement international standards. The explanatory findings are an input for reformers and legislators when designing and developing financial information reforms.

Keywords: Comparative public accounting, IPSAS, local government, central government accounting reform

\section{Introduction}

One of the most important aspects of New Public Management (NPM) is the tendency of reforms in financial information systems. These changes are an essential element to improve the management and decision-making of government institutions, which is also called New Public Financial Management (NPFM) (Guthrie, Olson and Humphrey, 1999). The cornerstone of reforming financial information systems is the introduction of accrual accounting in the public sector, at the expense of traditional cash accounting systems (Lapsley, 1999). Several governments have been adopting and implementing accrual accounting systems. Different authors (Pina and Torres, 2003; Groot and Budding, 2008) emphasize the advantages of introducing accrual accounting in a governmental context. Accrual accounting as defined and introduced by NPM reforms, provides more and accurate information about government 
solvency, patrimonial goods and the costs of public services (Pina and Torres, 2003: 335). Since the last decade the International Public Sector Accounting Standards Board (IPSASB), which used to be the Public Sector Committee (PSC) of the International Federation of Accountants (IFAC), has developed a set of International Public Sector Accounting Standards (IPSAS), in order to streamline and support these reforms.

Based on a former comparative study limited to the European situation (Christiaens et al. 2010) and on newly gathered evidence in countries worldwide this study aims to shed a light on the actual level of reforms of the financial information systems, particularly in the direction of the adoption of the IPSAS. Secondly and particularly for European countries, this paper compares to current situation with the level of adoption found in 2009 (Christiaens et al. 2010).

This paper attempts to contribute to the comparative studies in public sector accounting. Some authors, such as Benito, Brusca and Montesinos (2007), Brusca and Condor (2002), have made contributions to comparative accounting studies in the public sector. Most of them however focus on a small sample of countries or on a particular aspect of the accounting legislation. There are also a few surveys mostly developed by consulting firms (e.g. Ernst \& Young 2012, PWC 2013) presenting an international overview and highlighting current practices, but are not meant to serve a scientific purpose. It is the aim of this paper to compare the adoption of accounting systems, in relation to IPSAS, within a broader international context. Furthermore, while different papers only focus on the actual state of the adoption or implementation of an accounting system, this study also attempts to point to the reasons why governments choose for a specific accounting system.

Following this introduction, a theoretical explanation of accrual accounting reforms is given and literature on reasons creating differences in accounting practices is presented, as well as environmental characteristics of continents observed. Emphasis is placed on the efforts concerning the international harmonization of accounting standards. Chapter 3 and 4 provide the research objectives and the methodology of this paper. Next, the results are presented. Finally, the main findings of this research paper are summarized.

\section{What affects financial information systems: a literature review}

The worldwide process of globalization in economic activity has pushed for globalization also in accounting principles and practices: it is a fact that in the private sector there is a demand for harmonization, as demonstrated by the enlarged adoption of IAS/IFRS and the convergence project of FASB/IASB (Nobes, 2011). The process of converging accounting standards aims to enhance the international comparability of financial statements, in order to satisfy the information needs of different kinds of stakeholders on international markets (Choi, 2003). Nevertheless, as highlighted by the environmental theory (Choi and Mueller, 1992; Nobes and Parker 2004; Zeff, 2012), the application of accounting standards differs for different purposes. Even in the public sector there is a growing interest toward a widespread adoption of generally accepted accounting principles, resulting in the unique IPSASs. These standards aim to improve the comparability at different governmental levels. For many years budgetary accounting has been the mainstream accounting and financial information system in the public sector (IFAC 2008; IFAC PSC 2000). Most of governments conceptually need budgetary accounting to manage budget appropriations, i.e. in the context of the yearly discussion and approval as well as follow up of their budgets to spend. During the last decades and driven by NPM many governments have reformed their accounting system towards accrual accounting. 
The work made by the IPSASB has revived the discussion about harmonization in the public sector. Similarly to previous research in the business sector, certain studies (Brusca and Condor 2002; Pina and Torres, 2003) have demonstrated that the development of national accounting systems tends to be a function of different institutional attributes and environmental factors. Culture has been defined by Hofstede as 'the collective programming of the mind which distinguishes the members of one human group from another' (1980: 25). Also environmental factors - including legal systems, sources of external finance, taxation systems, and representation by professional accounting bodies, historical inflation, economic and political events - have been largely adopted to help in explaining international differences in accounting practices (Nobes and Parker, 2004: 17-31). Anyhow, most of the studies try to identify patterns and influential factors with reference to business accounting (Muller, 1967; Gray, 1988; Nobes 1998; Zeff, 2012) while very few studies examined the public sector (a synthesis in Baker and Barbu, 2007). Despite a large number of New Public Management (principles and criteria) reforms around the world different accounting systems are still spread world-wide. As the present study highlights, these NPM reforms tend to adopt accounting systems based on accruals as a tool to gain a wider accountability in a democratic system and in a free market (Chan, 2003).

Many scholars have highlighted how the implementation of accrual-based accounting systems, as an alternative to cash-based or obligation based systems would not be necessarily consistent with the main characteristic of public entities (Mack and Ryan, 2006; Christiaens and Rommel, 2008). On the other hand, it has also been pointed out (Fédération des Experts Comptables Européens, 2007; Christiaens et al., 2010) that cash-based accounting does not allow obtaining the necessary information in order to provide better support for planning and managing resources and more generally for decision-making processes, allowing greater comparability, even between different entities.

It has also been hypothesized that a significant boost toward harmonization can be derived from the financial market and rating agencies: nevertheless, according to Ingram (1983), this boost is effective especially for countries that largely approach financial markets, where a decrease in financial costs can cover the costs arising from a change in the accounting systems. This hypothesis, even if fascinating in our context, with a financial crisis affecting almost all countries, is difficult to test empirically. As already highlighted by Chan (2006), relevant citizens' expertise and awareness as well as their socio-economic status can be relevant as well as the role played by politicians and managers in the plain adoption of accounting systems' change.

Among organizational studies, scholars emphasized the existence of isomorphism trying to explain changes, especially the ones related to the international standardization (Burn and Scapens, 2000) inside neo-institutional theory (Meyer and Rowan, 1977). According to this approach, similar organizations tend to conform each other and they became more similar, in order to obtain institutional legitimacy. According to Powell and Di Maggio (1983), the adaptation process is stronger when the organization depends on external resources and, at the same time, has any certainty on their own goals. Essentially, while some scholars prefer to consider institutional factors, others give more relevance to behaviour and culture.

In relation with the adoption of IPSASs - more than for the adoption of single standard - the problem arising is the effective need of harmonization. Looking at the literature on the matter, it seems that accounting harmonization could not be avoided, it is self-explaining and somehow inherent to the idea that any transaction would be accounted for according with the same rules everywhere (Pina et al., 2009). 
Different authors state that the international trend towards modernizing the financial information system is likely to continue during the following years (Lüder and Jones, 2003; Grossi and Soverchia, 2011). An important stimulus in this evolution is the support of international organizations such as OECD, NATO, United Nations, the European Commission and Interpol. All these influential organizations promote sound financial management and accountability. Such "good practices" have a moral influence on different countries around the world. In addition, the International Organization of Supreme Audit Institutions (INTOSAI, 2005) promotes the use of IPSAS (Algemene Rekenkamer, 2003). In light of the above literature review, the present research aims to highlight differences in the adoption of (IPSAS(like)) accrual accounting worldwide.

\section{Research objective}

Although the trend of adopting accrual based accounting systems in the public sector occurs, different systems are adopted. These differences are situated at three levels: (1) the content, (2) the timing of the adoption and (3) how accrual accounting will be applied. Both National (Carvalho et al., 2007) as well as international studies (Christiaens et al., 2010) showed that there is a great diversity in the way the accounting reforms are implemented in local governments within one country as well as in local governments between countries. Due to the non-enforceable mechanisms of IPSAS and the lack of penalty, many governments look at their own needs and do not fulfil all requirements prescribed by IPSAS. If each country adopts accrual accounting systems according to their own particular necessities, accrual accounting reforms will not be homogenous. It can be stated that, in spite of the international implementation of accrual accounting, the financial information systems in the public sector are still relatively divergent (Brusca and Condor, 2002; Lüder and Jones, 2003; Pina and Torres, 2003; Benito, Brusca and Montesinos., 2007; Carvalho et al., 2007; FEE, 2007).

There is also a significant diversity in the timing of the adoption process. Some countries are intensively investing in modernizing their accounting systems. Countries that lead the bunch are mainly Anglo-Saxon (Australia, New Zealand, the United Kingdom and the United States), while other countries choose a more conservative approach (OECD, 2002; Carlin, 2005; Van Der Hoek, 2005; Benito et al., 2007; Groot and Budding, 2008; Christiaens et al., 2010).

A third difference refers to the way in which accrual accounting is adopted. Some countries have a decentralized vision, which means that the accrual accounting reforms are first developed at the municipal level before they are introduced in the central government (e.g. Sweden). Other jurisdictions impose the introduction of NPFM reforms in a more centralist way (e.g. New Zealand) (Olson, Guthrie and Humphrey, 1998; Guthrie, Olson, and Humphrey, 1999; Groot and Budding, 2008).

This study can be seen as a sequel to the comparative European study of Christiaens et al. (2010) from a worldwide perspective. It is the aim of this paper to study the different levels of adopting accrual accounting across different countries. The focus is on the level to which accrual accounting is adopted. This study does not aim to focus on the content related differences of accrual accounting. This work has already been done by other authors such as Benito et al., 2007. Therefore the first research question is the following. 
RQ 1: To what extent is (IPSAS-like) accrual accounting adopted in central / local governments in countries worldwide and particularly for European countries: what are the changes between the situation studied in 2009 and the current situation?

This study focuses on the adoption of new governmental information systems, i.e. the decision of the legislator or standard setter to prescribe a specific accounting system. The adoption is an important issue as it is the first step of the whole reform process. The implementation of the prescribed accounting system is a next phase of the reform process. Some authors (Brusca and Condor, 2002; Pollitt and Bouckaert, 2004; Benito et al., 2007) have proven that there is a great diversity in the implementation of structural (accounting) reforms. However, the way and the status of implementing the accounting regulations is beyond the scope of this research paper and could be a topic for further research. It is the preceding phase of developing and adopting modernized information systems, in the light of international standards, that will be examined in this paper.

For local as well as for central governments the study of Benito et al. (2007) reveals that there is a reasonable degree of coincidence with the IPSAS, but they also prove that there is a lack of homogeneity between different accounting systems in the European Union. The study even states that diversity is a main characteristic of financial reporting in local and central governments. The current paper tries to enrich the accounting literature by investigating the reasons of this diversity. Therefore the second research question is defined as follows.

RQ 2: What explains the differing level of adopting IPSAS in different levels of government? One might argue that culture and tradition play an important role in this respect.

\section{Methodology}

In order to investigate these research questions, a field study across 81 countries / jurisdictions was set up by means of a survey (Christiaens et al. 2010). The UN list of countries ${ }^{1}$ was taken as sampling frame, and a first selection was made by excluding all countries with less than 1 million inhabitants, because of their limited size. Secondly, the possibility to reach certain academics, practitioners and officials (the three groups of experts) was taken into account, which further decreased the list of potential target countries. For reasons of comparison, there is made sure that all countries included in the previous study (Christiaens et al. 2010) were also part of the current sample.

The differences in culture, historical context or in structural elements of each country may influence the public sector reforms and the accounting systems (Benito et al., 2007; Pina et al., 2009). To explain the different features of public sector reforms undertaken all over the world, the countries are grouped in six groups according to their different styles of public management (Brusca and Condor, 2002; Pina et al., 2009): old Europe, New Europe, Anglo-Saxon countries, Latin America, Africa and Asia.

The study covers local governments as well as their overall central governments. In most countries the central government is the national government. However, in Germany and in Belgium the so-called Bundesländer and Communities are highly independent and differ strongly with respect to the adoption of accrual accounting and IPSAS. Both of the communities in Belgium as well as two representative Bundesländer were selected. 
Based on a number of credentials (publications, years of experience, etc.) a sample of three experts, i.e. an academic, a professional and a consultant, were selected in each jurisdiction or country. The academics are mainly professors and researchers specialized in public sector accounting. They were selected on the basis of previous published research documents and articles. The professionals (of central and local governments) are people of at least a middle level, who are daily involved in governmental accounting issues. All selected consultants belong to a big-four accounting firm and are experienced in public sector accounting activities. The questionnaire remains mainly the same as in previous research (Christiaens et al. 2010) except for some slight improvements.

The responses to the questionnaire were not the only source of data. Because of the increasing occurrence of e.g. IPSAS Board reports and presentations as well as social media such as LinkedIn IPSAS groups, additional information regarding on-going accounting reforms in certain countries/ jurisdictions was gathered to improve the responses to the questionnaires.

\section{Results}

After sending second and third requests, we obtained 100 useful questionnaires representing 59 countries/jurisdictions in March 2012. The majority of respondents were 48 academics, followed by 33 officials and 19 accounting consultants. This leads to a comparative study in 59 countries/jurisdictions all over the world as represented in Table 1 and 2. It is also important to clarify the interpretation of the results coming from the three different experts. Regarding the first research question as reflected in Tables 1 and 2 the answers of the experts are quite coincident, with only few mismatches. In order to clear these mismatches a re-examination whereby the experts were contacted aiming at reconciling their points of view, was conducted. Additionally, the current situation of the according jurisdiction was examined more precisely based on official data from the jurisdiction. Considering the Tables 3 and 4 in which the different reasons were examined, the three experts appeared to result in complementary answers, because the number of earmarked answers was not limited.

Table 1 gives an overview of the financial information systems in respectively European governments and in governments of the rest of the world. Panel A shows the situation in local governments, panel B gives the same information for the central governments. The first column enumerates all the countries/jurisdictions. The second column (i.e. "IPSAS") shows those jurisdictions that are fairly match IPSAS, implying a reasonable conformity with all of the actual 32 IPSAS standards covering the accounting measurement basis, valuation rules as well as the annual accounts. It is possible that some of them have minor exceptions to IPSAS (e.g. one of the standards has not yet fully been adopted, regarding the valuation of plant and equipment certain goods are excepted, etc.), but in general they are based on IPSAS.

The third column shows the jurisdictions that currently account on a cash basis but are planning to introduce an IPSAS(-like) accrual accounting system in the near future. This column is also relevant because the transition to IPSAS or to accrual accounting often necessitates a number of years to consider, prepare, plan and decide its adoption.

Column 4 (i.e. "accrual accounting”) represents jurisdictions that do not choose for IPSAS, but apply another form of accrual accounting. IPSAS is a form of accrual accounting derived from the IAS/IFRS standards, but as shown in Christiaens et al. (2010) in a number of countries governments apply accrual accounting inspired by their business accounting rules. The 
"planned accrual reform" column lists the jurisdictions that still account on a cash basis, but are planning to transform their accounting system to a non IPSAS accrual version. Those jurisdictions that account on a cash basis and not plan to introduce an accrual accounting system are shown in the last column.

\section{Insert table 1 about here}

Figures 1and 2 show the comparison of the 2009 study for "old" Europe (Christiaens et al. 2010) with the according 2012 figures for "old" Europe. This comparison in time reveals for local governments financial information systems move from budgetary accounting to accrual accounting and even to IPSAS. As a matter of fact in "old" Europe none of the local governments still apply just the cash accounting system. Regarding central governments this effect is less present and about $17 \%$ of the "old" European central governments still resist to any change of their cash accounting system. In the examined sample there are even a few jurisdictions that turned the clock back. On the other hand the adoption of accrual accounting, particularly IPSAS is rising, albeit slightly. These findings are in line with the recently published results after public consultation - Assessment of the suitability of IPSAS for the EU member states (EC Eurostat, 2012). 38\% of the 68 respondents answered that they considered IPSAS to be suitable for implementation. However, $28 \%$ were against and $31 \%$ of the respondents were only partly in favour. Apparently, there remains an important level of resistance and this confirms the findings in current study.

In the majority of these countries the weak internal harmonization (among different levels of government) reflects on the external harmonization among States (Caperchione, 2012). For example vertical harmonization is strong in the UK and Sweden and it is weak or only partial in Italy, France and Spain. Nordic countries such as Sweden, Finland, Denmark and The Netherlands were leaders in NPM developments and the introduction of accrual accounting in the central government is related both to management devolution and to territorial decentralization (Pina et al., 2009; Oulasvirsta, 2012).

In countries of the new Europe the public sector accounting reforms have suffered from multiple changes in order to modernize the financial information system. For some of them (e.g. Romania and Ukraine) the transition has not been easy particularly in the years after the end of communism and the beginning of the capitalist era (Albu et al., 2010). On the other hand the former Eastern European countries appear to adopt more intensively the IPSAS system. This can be explained by their striving for adhesion to the EU as well as by the "Law of stimulating arrears"3 (de Wit, 2011).

\section{Insert figure 1 about here}

\section{Insert figure 2 about here}

\section{Insert table 2 about here}

As could be expected based on previous research (Pina et al., 2009) the Anglo-Saxon countries are used to apply accrual accounting in their central as well as local governments. Some have explicitly decided to implement IPSAS, others prefer IFRS being very close to IPSAS. The USA have their own accrual accounting system being GASB for local authorities or FASAB for their central state. The second exception is Ireland because of their general tendency not to embrace NPM ideas with excessive enthusiasm (Connolly and Hyndman, 2009). Although 
some countries actually have somewhat Anglo-Saxon roots like e.g. Kenya, African countries mostly represent the cash accounting system. The majority of African countries has a bureaucratic and centralized system; the accounting traditions are weak because African countries have been strongly colonized with consequent influence of English, French, etc. traditions (Muiu, 2010). Historically, developing countries have lacked a rigorous public sector accounting framework and this has probably been a contributing factor to high levels of wastage and corruption in some of these countries (Jreisat, 2010). According to Chan (2006) the adoption of IPSAS in developing countries often requires a large investment in educating and training people to develop a new range of accounting skills. This is not always possible in countries where governments only have limited resources.

Latin America reveals a favouring situation for accrual accounting, particularly for IPSAS. This finding is in line with the so-called second-generation reforms whereby public budgets and modernization of management and public finance became necessary (Caba Pérez and López Hernández, 2007). This is also the case in the Asian continent where many jurisdictions strive for implementing accrual accounting and IPSAS. In recent years, Asian countries have undertaken significant economic and political reforms aimed at improving the quality of democracy, strengthening the accountability and transparency of the public sector and combating corruption (Prasojo, Kurniawan and Holidin, 2007).

From a worldwide perspective $44 \%$ of the local governments have developed an IPSAS-like accounting system, whereas 39\% are involved in accrual accounting. For central governments the former is about $51 \%$ and the latter $22 \%$. One can conclude that there are still an important number of central governments applying cash accounting compared with local governments, but in the group of governments that have chosen for accrual accounting like systems, central governments prefer the IPSAS-like accrual accounting system.

Table 3 shows the reasons why jurisdictions make use of IPSAS when reforming their financial information system. Apparently, the majority of the jurisdictions that apply IPSAS do this to enhance (inter)national comparability of financial information, also facilitating the consolidation of financial statements. However, one could argue that this important worldwide expectation in the mind of governments will not be sufficiently achieved by adopting IPSAS because the IPSAS do not define the structure of financial statements. As a matter of fact the IPSAS also leave a number of valuation options, e.g. IPSAS 17 Property, plant and equipment allows two different valuation policies, being the cost model or the revaluation model. On the other hand the IPSAS are worldwide almost unique and provide a common platform to enable converging practices. This convergence is necessary because financial reporting should be harmonized to become comparable and the current sometimes divergent adoption of IPSAS explains somehow why entities chose not to apply IPSAS.

Also important in Table 3 is the accordance with international organizations. The comparison between public and private sector seems to be less important. The ranking of the reasons is almost the same between local and central government, although the different items of motivation are more stressed for central governments. In other words the adoption of IPSAS(like) systems in central governments is considered as more relevant than in local governments. Regarding the examined geographic regions, there does not appear to be a relevant difference. The responses from the different geographic regions indicate more or less the reasons, e.g. the maximum of the reason "To enhance (inter)national comparability of financial information" of 21 for local governments is shared by "Old" Europe, Africa and Americas as their most important reason, e.g. the minimum of the reason "To improve public/private comparability" of 
9 for local governments is shared by "Old" Europe, Americas and Anglo-Americans as their least important reason.

\section{Insert table 3 about here}

The main reasons why some jurisdictions are interested in consulting IPSAS when reforming their accounting legislation are summarized in Table 4. Similar to a previous study (Christiaens et al., 2010) one of the most important reasons not to adopt IPSAS is the existence of dominating local or country-wise business accounting rules. Countries in which such business accounting rules are well-known and accepted will strive for transferring them to their governmental sector, whereas countries that are not used to accrual accounting systems appear to change their accounting systems more fundamentally to international accepted standards being IPSAS. Examples can be found in Eastern European countries formerly dominated by communist influences. As such, governments applying the local business accounting rules deliver more comparable financial reports next to the IPSAS-like countries, albeit that often the local business accounting rules are often country bound and are less comparable. Other crucial factors to not apply IPSAS still are the fear of losing its standard setting authority, the unfamiliarity with IPSAS and the lack of attention for budgetary accounting.

\section{Insert table 4 about here}

A rather positive conclusion is the fact that Table 3 exceeds the number of answers shown in table 4, which implies a general favoring of IPSAS more than disregarding them. However, a number of understandable negative assessments remain.

The worldwide overview of the financial systems and the reasons to link and not to link the accrual accounting legislation to IPSAS evidences that the currents public sector accounting systems are subject to different points of view and backgrounds. Table 5 summarizes the main institutional factors influencing the current and future accounting systems in the countries all over the world (Nobes and Parker 2004; Pina et al. 2009; Zeff, 2012). Interpreting the results in light of the institutional factors mentioned we could say that the tendency to apply the accrual accounting and IPSAS is stronger in countries with participating legislative systems, a democratic citizens' participatory style, with a strong accounting tradition, with a vertical harmonization and with a centralized financial system (Adhikari et al., 2010; Muiu, 2010; Caperchione, 2012).

\section{Insert table 5 about here}

\section{Conclusion}

The intention of this research was to develop a sequel study regarding the level of adopting IPSAS of the previously examined European governments (Christiaens et al. 2010) to all local and central governments worldwide. This offers two new perspectives being a comparison of the previously examined European situation in 2009 vs. 2012 and the possibility to extend the European situation to a worldwide comparison.

Apart from data directly coming from the IPSAS Board and the according notes and publications, a survey sent to three kinds of experts of the different sampled jurisdictions resulted in data collection of 59 jurisdictions worldwide. The survey mainly consisted of factual questions next to a set of perceptive questions. The importance of the interpretation of the 
results coming from the three different experts is clear. A revision of the few mismatches whereby these experts were contacted was conducted. The answers of the experts were complementary and quite coincident.

When comparing the European situation 2009 and 2012, the examination undoubtedly reveals an important move to accrual accounting, particularly to IPSAS. All of the "old" European local governments have adopted at accrual accounting and in the "old" European central governments only about $17 \%$ are still limited to just cash accounting. On the other hand it can be noticed that there remains an important number of local (about 28\%) as well as central governments (about 33\%) that have planned to implement accrual accounting, particularly IPSAS. In other words, the length and importance of the planning stage should not be underestimated. Secondly, the $17 \%$ of the central government keeping their cash system unchanged indicates some reluctance probably due to their more explicit political need for budgetary accounting and their important macro-economic perspective.

The figures in the "new" European countries reveal a differing situation, which can be explained by the different timing of state reforms those countries underwent. A second explanation are the rather emerging countries, which often need IMF support and which make use of the IPSAS when reforming their financial information systems from a resource dependence theory point of view.

Although one can argue about the definition of countries belonging to the Anglo-Saxon world, it is rather clear that the tendency to accrual accounting and IPSAS or IFRS, which is close to IPSAS, appears. This is probably also due to the "principles-driven" character behind IFRS and IPSAS, which is an Anglo-Saxon feature instead of the rather "rules-driven" legally defined accounting prescriptions existing in continental European countries and in their former colonies.

Like in previous study (Christiaens et al. 2010) the main reasons to use the IPSAS standards is the conviction that the adoption of IPSAS will improve the (inter)national comparability of financial information and to facilitate the consolidation of financial statements. Some jurisdictions, on the other hand, choose to not apply the IPSAS. The reasons to do this are double. Firstly, important weaknesses are the fear of losing their standard setting authority and the fact that the IPSAS are still relatively unknown. The second reason why some jurisdictions choose to not apply the IPSAS is because they have chosen for implementing their own business accrual accounting regulations, which fits in the "Law of the handicap of a head start". This slows down the IPSAS compliance process. In order to overcome this, a cultural change as well the necessary enforceability of the IPSAS is necessary.

\section{Notes}

1. http://unstats.un.org/unsd/methods/m49/m49alpha.htm

2. Former Yugoslav Republic of Macedonia

3. The "Law of stimulating arrears" is based on the "Law of the handicap of a head start" (in Dutch: Wet van de remmende voorsprong) developed by Jan Romein in 1937 "The dialectics of progress" (in Dutch: De dialectiek van de vooruitgang), Amsterdam: Querido, p. 9-64.

4. Multiple reasons simultaneously possible

\section{List of abbreviations used}




$\begin{array}{ll}\text { EU } & \text { European Union } \\ \text { FASAB } & \text { Federal Accounting Standards Advisory Board } \\ \text { FEE } & \text { Fédération des Experts Comptables Européens } \\ \text { GASB } & \text { Governmental Accounting Standards Board (USA) } \\ \text { IAS } & \text { International Accounting Standards } \\ \text { IFAC } & \text { International Federation of Accountants } \\ \text { IFRS } & \text { International Financial Reporting Standards } \\ \text { INTOSAI } & \text { International Organization of Supreme Audit Institutions } \\ \text { IPSAS } & \text { International Public Sector Accounting Standards } \\ \text { IPSASB } & \text { International Public Sector Accounting Standards Board } \\ \text { NPM } & \text { New Public Management } \\ \text { NPFM } & \text { New Public Financial Management } \\ \text { OECD } & \text { Organization for Economic Cooperation and Development } \\ \text { PSC } & \text { Public Sector Committee } \\ \text { UN } & \text { United Nations }\end{array}$

\section{References}

Adam B and Mussari R and Jones R (2011) The diversity of accrual policies in local government financial reporting: an examination of infrastructure, art and heritage assets in Germany, Italy and the UK. Financial Accountability \& Management 27(2): 106-133.

Adhikari P and Mellemvik F (2010) (forthcoming) The Adoption of IPSASs in South Asia: A Comparative Study of Seven Countries. Research in Accounting in Emerging Economies, 10: 171-201.

Albu CN, Albu N and Alexander D (2010) Accounting change in Romania-a historical analysis. In: 6th workshop on European Financial Reporting EUFIN (pp. 1-2).

Algemene Rekenkamer (2003) Begroting en verantwoording in balans. Het baten-lastenstelsel voor de rijksoverheid, Tweede Kamer, vergaderjaar 2002-2003, 28 860, No. 1-2, Sdu Uitgevers, Den Haag.

Baker R and Barbu E (2007) Trends in research on international accounting harmonization, The International Journal of Accounting 42: 272-304.

Benito B Brusca I and Montesinos V (2007) The Harmonization of Government Financial Information Systems: the Role of the IPSASs. International Review of Administrative Sciences 73(2): 293-317.

Brusca I and Condor V (2002) Towards the Harmonisation of Local Accounting Systems in the International Context. Financial Accountability \& Management 18(2): 129-162.

Caba Pérez C and López Hernández AM (2007) Latin-America Public Financial reporting: recent and future development. Public Administration and Development 27(2): 139-157.

Caperchione E (2012) L'armonizzazione contabile nella prospettiva internazionale. Azienda Pubblica 1: 83-99.

Carvalho J Jorge S and Fernandes M (2007) Conformity and Diversity of Accounting and Financial Reporting Practices in Portuguese Local Government. Canadian Journal of Administrative Sciences 24(1): 2-14.

Chan JL (2003) Government Accounting: An Assessment of Theory, Purposes and Standards. Public Money \& Management, 1: 13-19.

Chan JL (2006) IPSAS and government accounting reform in developing countries. Accounting Reform in the Public sector: Mimicry, Fad or Necessity, 31-42.

Choi FDS (2003) International accounting and finance handbook. (3rd Ed.), Wiley and Sons. 
Choi FDS and Mueller GG (1992) International accounting, II Edition. Prentice Hall International, Englewoods.

Christiaens J and Rommel J (2008) Accrual Accounting Reforms: Only for Businesslike (Parts of) Governments. Financial Accountability \&Management 24(1): 59-75.

Christiaens J Reyniers B Rollé C (2010) Impact of IPSAS on Reforming Governmental Financial Information Systems: A Comparative Study. International Review of Administrative Sciences 76(3): 537-554.

Connolly C and Hyndman N (2009) The Implementation of Accruals Accounting in the Irish Public Sector: A Comparative Study of Northern Ireland and the Republic of Ireland. Accounting Perspectives, Chartered Accountants Ireland, Dublin.

De Wit JWH (2011) De wet van de stimulerende achterstand. HVA Publicaties, Amsterdam.

EC Eurostat (2012) Public Consultation - Assessment of the suitability of the IPSAS for the Member States. Luxembourg.

Ernst \& Young (2012) Overview and comparison of public accounting and auditing practices in the 27 EU Member States, Final Report, 19 December 2012.

FEE (2007) Accrual Accounting in the Public Sector, Paper from the FEE Public Sector Committee.

Gray S J (1988) Towards a Theory of Cultural Influence on the Development of Accounting Systems Internationally. Abacus 24: 1-15.

Groot T and Budding T (2008) New Public Management's Current Issues and Future Prospects. Financial Accountability \& Management 24(1): 1-13.

Grossi G and Soverchia M (2011) European Adoption of IPSAS to Reform Financial Reporting. Abacus 47(4): 525-552.

Guthrie J Olson O and Humphrey C (1999) Debating Developments in New Public Financial Management: The Limits of Global Theorising and some new Ways Forward. Financial Accountability \& Management 15(3-4): 209-228.

Hofstede G (1980) Culture's Consequences: International Differences in Work-Related Values. Beverly Hills CA: Sage Publications.

IFAC (2008) IFAC Handbook of International Public Sector Accounting Pronouncements. New York.

IFAC PSC (2000) Study 11 - Government Financial Reporting: Accounting Issues and Practices. New York.

Ingram RW (1983) The Importance of State Accounting Practices for Credit Decisions. Journal of Accounting and Public Policy 2, Spring: 5-19.

INTOSAI (2005) Strategic Plan 2005-2010, INTOSAI.

Jreisat J (2010) Comparative public administration and Africa. International Review of Administrative Sciences, 76 (4): 612-631.

Lapsley I (1999) Accounting and the New Public Management: Instruments of Substantive Efficiency or a Rationalising Modernity. Financial Accountability \& Management 15(3-4): 201-207.

Lüder K and Jones R (2003) Reforming Governmental Accounting and Budgeting in Europe. Fachverlag Moderne Wirtschafts, Frankfurt am Main.

Muiu MW (2010) Colonial and postcolonial state and development in Africa. Social research: an international quarterly 77(4): 1311-1338.

Muller GG (1967) Accounting Principles Generally Accepted in U.S. Versus those Accepted Elsewhere. The International Journal of Accounting Education and Research 3(2): 99-103.

Nobes C (1998) Towards a General Model of the Reasons for International Differences in Financial Reporting. Abacus 34: 162-187.

Nobes C (2011) IFRS Practices and the Persistence of Accounting System Classification. Abacus 47: 267-283. 
Nobes C and Parker R (2004) Comparative International Accounting, Eighth edition. Pearson Education Limited, England.

OECD (2002) Models of Public Budgeting and Accounting Reform, OECD Journal on Budgeting Volume 2, Supplement 1, OECD Publications, Paris.

Olson O Guthrie J and Humphrey C (1998) Global Warning: Debating International Developments in New Public Financial Management. Cappelen Akademisk Forlag, Oslo.

Oulasvirta L (2012) The reluctance of a developed country to choose International Public Sector Accounting Standards of the IFAC: A critical case study. Critical Perspectives on Accounting, In Press, Available online, http://dx.doi.org/10.1016/j.cpa.2012.12.001

Pawan A and Mellemvik F (2010) IPSASs in Developing Countries: A Case of Nepalese Central Government. International Journal of Governmental Financial Management, X(2): 36-48.

Pina V and Torres L (2003) Reshaping Public Sector Accounting: An International Comparative View. Canadian Journal of Administrative Sciences 20(4): 334-350.

Pina V Torres L and Yetano A (2009) Accrual accounting in EU Local Governments: One Method, Several Approaches. European Accounting Review 18(4): 765-807.

Pollitt C and Bouckaert G (2004) Public Management Reform: A Comparative Analysis. Oxford University Press, Oxford.

Prasojo E Kurniawan T and Holidin D (2007) An analysis of the government systems in Indonesia. A working paper at the University of Indonesia.

PWC (2013) Towards a new era in government accounting and reporting, April 2013.

Van Der Hoek MP (2005) From Cash to Accrual Budgeting and Accounting in the Public Sector: The Dutch Experience. Public Budgeting \& Finance 25(1): 32-45.

Zeff SA (2012) The Objectives of Financial Reporting: a Historical Analysis, paper presented at ICAEW 's Information for better markets Conference, December, 17th, London. 
Table 1 Overview of financial information systems Europe

\begin{tabular}{|c|c|c|c|c|c|}
\hline Jurisdictions Europe & IPSAS & $\begin{array}{l}\text { Planned } \\
\text { IPSAS } \\
\text { reform }\end{array}$ & $\begin{array}{c}\text { Accrual } \\
\text { accounting }\end{array}$ & $\begin{array}{l}\text { Planned } \\
\text { accrual } \\
\text { reform }\end{array}$ & $\begin{array}{c}\text { Cash } \\
\text { accounting }\end{array}$ \\
\hline Austria & - & $\mathrm{A} \square \mathrm{B} \square$ & - & - & - \\
\hline Baden-Württemberg (Ger) & - & - & - & $\mathrm{A} \square$ & $\mathrm{B}$ \\
\hline Denmark & - & $\mathrm{B} \square$ & $\mathrm{A} \square$ & - & - \\
\hline Finland & - & - & $\mathrm{A} \square \mathrm{B} \square$ & - & - \\
\hline Flanders (Bel) & $\mathrm{A} \square$ & - & $\mathrm{B}$ & - & - \\
\hline France & $\mathrm{B}$ & - & $\mathrm{A}=$ & - & - \\
\hline Greece & - & - & $A=$ & - & $\mathrm{B}$ \\
\hline Italy & - & - & - & $\mathrm{A} \square \mathrm{B} \square$ & - \\
\hline Lithuania & $\mathrm{A} \square \mathrm{B} \square$ & - & - & - & - \\
\hline Netherlands & - & - & $\mathrm{A}=$ & $\mathrm{B}$ & - \\
\hline Norway & - & - & $\mathrm{A} \square$ & - & $\mathrm{B} \square$ \\
\hline Portugal & - & - & $\mathrm{A} \square \mathrm{B} \square$ & - & - \\
\hline Saxony-Anhalt (Ger) & - & - & - & $\mathrm{A} \square \mathrm{B} \square$ & - \\
\hline Spain & $\mathrm{B}$ & $\mathrm{A} \square$ & - & - & - \\
\hline Sweden & $\mathrm{A} \square \mathrm{B} \square$ & - & - & - & - \\
\hline Switzerland & $\mathrm{A} \square \mathrm{B} \square$ & - & - & - & - \\
\hline UK & $\mathrm{A} \square \mathrm{B} \square$ & - & & - & - \\
\hline \multirow[t]{2}{*}{ Wallonia (Bel) } & - & - & $\mathrm{A} \square$ & $\mathrm{B} \square$ & - \\
\hline & $\mathrm{A} \square \mathrm{B}=$ & $\mathrm{A} \square \mathrm{B}=$ & $\mathrm{A} \square \mathrm{B}$ & $\mathrm{A} \square \mathrm{B} \square$ & $\mathrm{A} \square \mathrm{B}$ \\
\hline $\begin{array}{c}\text { Subtotal "old" Europe } \\
\%\end{array}$ & $\begin{array}{cc}5 & 6 \\
27.8 & 33.3\end{array}$ & $\begin{array}{cc}2 & 2 \\
11.1 & 11.1\end{array}$ & $\begin{array}{cc}8 & 3 \\
44.4 & 16.7\end{array}$ & $\begin{array}{cc}3 & 4 \\
16.7 & 22.2\end{array}$ & $\begin{array}{cc}0 & 3 \\
0 & 16.7\end{array}$ \\
\hline Czech Republic & - & - & - & $\mathrm{A} \square \mathrm{B} \square$ & - \\
\hline Croatia & - & $\mathrm{A} \square \mathrm{B} \square$ & - & - & - \\
\hline Hungary & - & - & - & - & $\mathrm{A} \square \mathrm{B} \square$ \\
\hline Estonia & $\mathrm{A} \square \mathrm{B} \square$ & - & - & - & - \\
\hline Latvia & $\mathrm{A} \square \mathrm{B} \square$ & - & - & - & - \\
\hline Fyrom $^{2}$ & - & - & - & - & $\mathrm{A} \square \mathrm{B} \square$ \\
\hline Malta & $\mathrm{A} \square$ & - & - & - & $\mathrm{B}$ \\
\hline Romania & - & - & $\mathrm{A} \square \mathrm{B} \square$ & - & - \\
\hline Slovakia & - & - & - & $\mathrm{A} \square$ & $\mathrm{B}$ \\
\hline \multirow[t]{2}{*}{ Ukraine } & - & $\mathrm{A} \square \mathrm{B} \square$ & - & - & - \\
\hline & $\mathrm{A} \square \mathrm{B} \square$ & $\mathrm{A} \square \mathrm{B} \square$ & $\mathrm{A} \square \mathrm{B} \square$ & $\mathrm{A} \square \mathrm{B} \square$ & $\mathrm{A} \square \mathrm{B} \square$ \\
\hline $\begin{array}{c}\text { Total Europe } \\
\%\end{array}$ & $\begin{array}{cc}8 & 8 \\
28.6 & 28.6\end{array}$ & $\begin{array}{cc}4 & 4 \\
14.3 & 14.3\end{array}$ & $\begin{array}{cc}9 & 4 \\
32.1 & 14.3\end{array}$ & $\begin{array}{cc}5 & 5 \\
17.9 & 17.9\end{array}$ & $\begin{array}{cc}2 & 7 \\
7.1 & 25.0\end{array}$ \\
\hline
\end{tabular}

$\mathrm{A} \square=$ Local Government, $\mathrm{B} \square=$ Central Government 
Figure 1. Financial information systems “old” Europe local governments

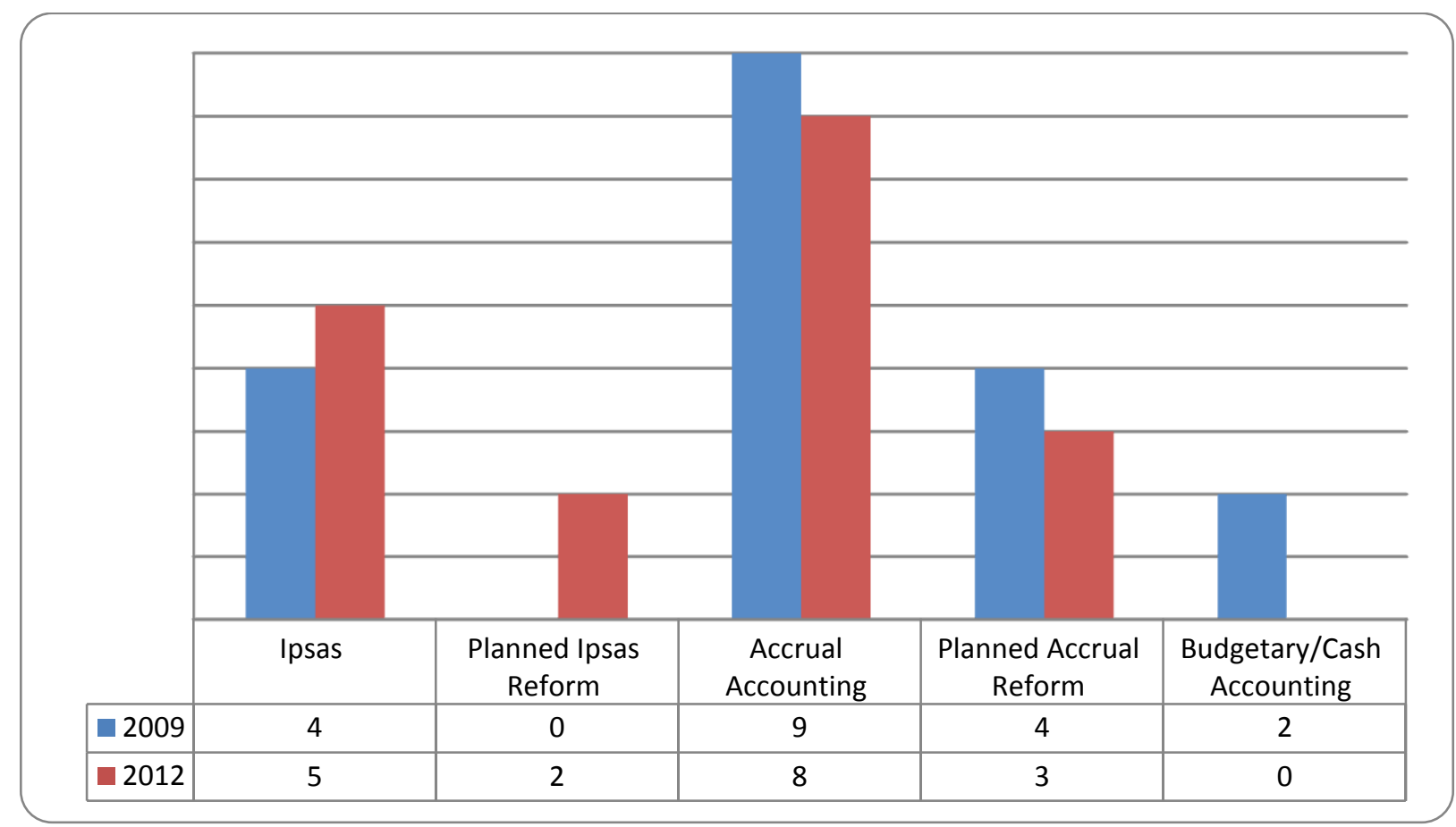

Figure 2. Financial information systems "old" Europe central governments

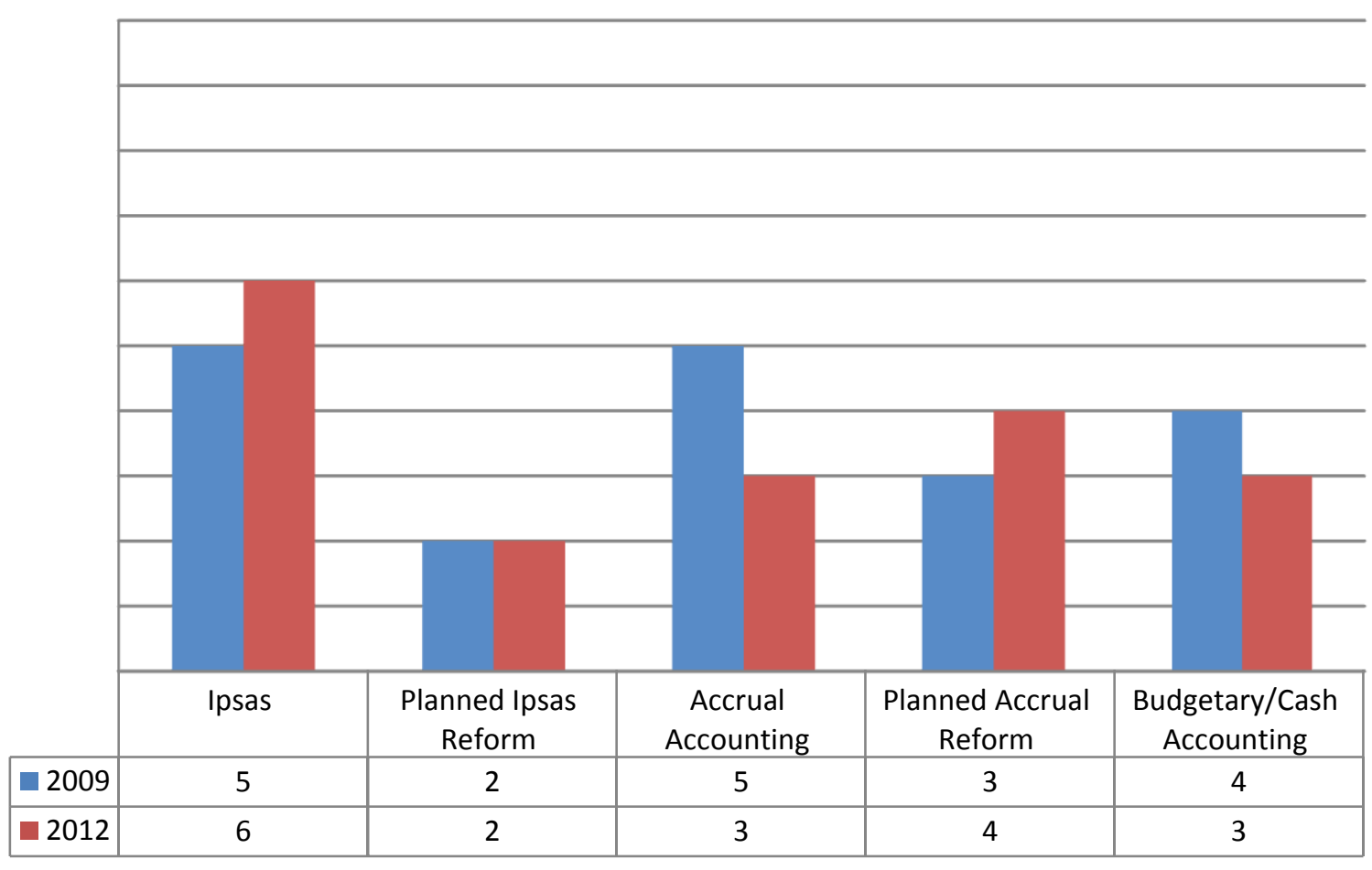


Table 2 Overview of financial information systems rest of the world

\begin{tabular}{|c|c|c|c|c|c|}
\hline A S Camalo & IPSAS & $\begin{array}{l}\text { Planned } \\
\text { IPSAS } \\
\text { reform }\end{array}$ & $\begin{array}{c}\text { Accrual } \\
\text { accounting }\end{array}$ & $\begin{array}{l}\text { Planned } \\
\text { accrual } \\
\text { reform }\end{array}$ & $\begin{array}{c}\text { Cash } \\
\text { accounting }\end{array}$ \\
\hline Australia & $A \square^{*} B \square^{*}$ & - & - & - & - \\
\hline Canada & $\mathrm{A} \square \mathrm{B} \square$ & - & - & - & - \\
\hline Ireland & - & - & $A \square$ & - & $B$ \\
\hline New-Zealand & $\mathrm{A} \square \mathrm{B} \square$ & - & - & - & - \\
\hline South-Africa & $A \boldsymbol{\square}$ & B & - & - & - \\
\hline UK & $A \square^{*} B \square^{*}$ & - & - & - & - \\
\hline USA & - & - & $A \square B=$ & - & - \\
\hline Total & 54 & $\begin{array}{ll}0 & 1\end{array}$ & 21 & - & $\begin{array}{ll}0 & 1\end{array}$ \\
\hline \multicolumn{6}{|l|}{ Africa } \\
\hline Democratic Rep Congo & - & - & - & - & $A \square B \square$ \\
\hline Egypt & - & - & - & - & $A \square B \square$ \\
\hline Kenya & - & - & $A=$ & - & $\mathrm{B} \square$ \\
\hline Madagascar & - & - & - & - & $A \square B \square$ \\
\hline Morocco & - & $B$ & - & - & $A=$ \\
\hline Mozambique & - & - & - & - & $A \square B \square$ \\
\hline Nigeria & - & - & - & - & $A=B \square$ \\
\hline Senegal & - & - & - & - & $A \square B \square$ \\
\hline Tanzania & - & - & $A=$ & - & $\mathrm{B}$ \\
\hline Uganda & - & $A \square B \square$ & - & - & - \\
\hline Total & - & $\begin{array}{cc}1 & 2 \\
10 & 20\end{array}$ & $\begin{array}{ll}2 & 0 \\
20 & 0\end{array}$ & - & $\begin{array}{cc}7 & 8 \\
70 & 80\end{array}$ \\
\hline \multicolumn{6}{|l|}{ Latin America } \\
\hline Brazil & - & $A \square B \square$ & - & - & - \\
\hline Chile & $A \square B \square$ & - & - & - & - \\
\hline Costa Rica & - & $A \square B \square$ & - & - & - \\
\hline Mexico & & $A \square B \square$ & & & \\
\hline Uruguay & - & $\mathrm{B}$ & - & - & $A \square$ \\
\hline Total & 11 & $\begin{array}{ll}3 & 4\end{array}$ & - & - & 10 \\
\hline$\%$ & 2020 & 6080 & & & 200 \\
\hline Asia & & & & & \\
\hline Bahrain & - & $A \square B \square$ & - & - & - \\
\hline China & - & - & - & $A \backsim B \square$ & - \\
\hline Indonesia & - & $\mathrm{A} \square \mathrm{B} \square$ & - & - & - \\
\hline Japan & - & - & - & $A \square B \square$ & - \\
\hline Malaysia & - & B & $A \square$ & - & - \\
\hline Russian Federation & - & $A \square B \square$ & - & - & - \\
\hline South Korea & - & - & $A \square B \square$ & - & - \\
\hline Turkey & - & $A \square B \square$ & - & & - \\
\hline United Arab Emirates & - & $A \square B \square$ & - & - & - \\
\hline Vietnam & - & $\mathrm{B}$ & - & - & $A \square$ \\
\hline Total & - & $\begin{array}{cc}5 & 7 \\
50 & 70\end{array}$ & $\begin{array}{cc}2 & 1 \\
20 & 10\end{array}$ & $\begin{array}{cc}2 & 2 \\
20 & 20\end{array}$ & $\begin{array}{ll}1 & 0 \\
10 & 0\end{array}$ \\
\hline Total worldwide & $\begin{array}{cc}13 & 12 \\
22.0 & 20.3 \% \\
\end{array}$ & $\begin{array}{cc}13 & 18 \\
22.0 & 30.5 \% \\
\end{array}$ & $\begin{array}{cc}15 & 6 \\
25.4 & 10.2 \%\end{array}$ & $\begin{array}{cc}7 & 7 \\
11.911 .9 \%\end{array}$ & $\begin{array}{cc}11 & 16 \\
18.6 & 27.1 \% \\
\end{array}$ \\
\hline
\end{tabular}


* A few Anglo-Saxon countries opted for IFRS unless certain accounting issues are not regulated by IFRS and reference needs to be made to IPSAS, IFRS are very close to IPSAS 
Table 3

Reasons to link the accrual accounting legislation to IPSAS ${ }^{4}$

\begin{tabular}{|c|c|c|}
\hline \multirow[t]{3}{*}{ A $\square$ Local Governments } & overn & ents \\
\hline & \multicolumn{2}{|c|}{ Frequency } \\
\hline & $\mathrm{A} \square$ & $\mathrm{B}$ \\
\hline - To enhance (inter)national comparability of financial information & 21 & 29 \\
\hline - To facilitate the consolidation of financial statements & 17 & 29 \\
\hline $\begin{array}{l}\text { - To be in accordance with international organizations (e.g. European } \\
\text { Commission, OECD , ...) }\end{array}$ & 14 & 20 \\
\hline $\begin{array}{l}\text { - It is useless to reinvent the wheel, it is more efficient to make use of the } \\
\text { knowledge of the IPSASB }\end{array}$ & 13 & 22 \\
\hline - To improve public/private comparability & 9 & 20 \\
\hline
\end{tabular}


Table 4

Reasons to not link the (planned) accrual accounting legislation to IPSAS ${ }^{4}$

A Local Governments

B Central Governments

\begin{tabular}{|l|l|}
\hline & Frequency \\
\hline
\end{tabular}

\begin{tabular}{|l|c|c|}
\hline & A & B \\
\hline - The acounting
\end{tabular}

- The accounting legislation is based on local business accounting rules

- There is a fear of losing the standard setting authority

- The IPSAS are rather unknown in my jurisdiction

- There is few experience in implementing the IPSAS

- The IPSAS do not consider budgetary accounting

- The IPSAS are based on IFRS/IAS and do not include important public sector issues

\begin{tabular}{|l|l|}
\hline 9 & 3 \\
\hline 9 & 8 \\
\hline 8 & 6 \\
\hline 4 & 4 \\
\hline 4 & 6 \\
\hline & \\
\hline 3 & 3 \\
\hline
\end{tabular}


Table 5

Institutional factors explaining the worldwide public sector accounting situation

\begin{tabular}{|c|c|c|c|c|c|}
\hline Countries & $\begin{array}{c}\text { Legislative } \\
\text { system }\end{array}$ & $\begin{array}{c}\text { Citizens' } \\
\text { partecipatory } \\
\text { style }\end{array}$ & $\begin{array}{c}\text { Relation } \\
\text { between } \\
\text { governments }\end{array}$ & $\begin{array}{c}\text { Accounting } \\
\text { tradition }\end{array}$ & $\begin{array}{c}\text { Financial } \\
\text { system }\end{array}$ \\
\hline Old Europe & Bureaucratic & Democracy & Decentralization & Strong & $\begin{array}{c}\text { Centralized/ } \\
\text { Authonomous }\end{array}$ \\
\hline East Europe & Bureaucratic & Authoritative & Decentralization & Weak & Centralized \\
\hline Anglo Saxon & Partecipative & Democracy & Centralization & Strong & Centralized \\
\hline Latin America & Bureaucratic & Authoritative & Centralization & Weak & Centralized \\
\hline Asia & Bureaucratic & $\begin{array}{c}\text { Authoritative } \\
\text { and Dictatorial }\end{array}$ & Centralization & Strong & Centralized \\
\hline Africa & Bureaucratic & $\begin{array}{c}\text { Authoritative } \\
\text { Corruption }\end{array}$ & Centralization & Weak & Centralized \\
\hline
\end{tabular}

